\title{
Utilization of stabilized yeast cream in pig fattening
}

\author{
(.) MEVRRLIR \\ Station de Recherches sur l'Élevage des Porcs, I. N. R. A., C.N.R. Z., \\ 78350 Jouy en Josas
}

Two groups of I l large White pigs were fed with a diet composed of Torula utilis yeast, in a constant amount ( $333 \mathrm{~g}$ dry matter/lay/animal) and of maize supplemented with vitamins and minerals, in restricted and increasing amounts till a maximum of $2.03 \mathrm{~kg} / \mathrm{day} / \mathrm{animal}$. One of the groups received the yeast in dry form, and the other group in liquid form stabilized by the addition of hydrochloric acid (till the obtention of $\mathrm{pH} 4.2)$ and of formol $(2 \mathrm{~g} / 1)$. The liquid yeast preparation was renewed each week and preserved for 8 days. The characteristics of the liquid yeast did not vary within this laps of time and it was well accepted by the pigs. Growth rates were 6r 2 $\mathrm{g} / \mathrm{d}$ and $644 \mathrm{~g} / \mathrm{d}$ respectively for liquid and dry yeasts, during the period between $3 \mathrm{I} .5$ and $92.7 \mathrm{~kg}$ live weight. Food conversion ratios were 3.09 and 2.94 respectively and body compositions were almost equivalent.

The poor improvement of performances in the case of dry yeast was only noticed in females and could be almost completely imputed to the relatively severe feed restriction applied. Utilization of stabilized yeast cream may therefore be considered as a favourable soybean oil-meal substitute for the fattening of pigs.

\section{Nutritive value of blood meal in replacement of soyabean oil-meal in growing-finishing pig diets}

\author{
A. RÉRAT, Y. HENRY* and D. BOLRDON* \\ Laboratoire de Physiologie de la Nutrition, \\ * Station de Recherches sur l'Elevage des Porcs, I. N. R. A., C. N. R. Z., \\ 78350 Jouy en Josas
}

With a view to estimating the nutritive value of blood meal in order to determine its limiting factors, an experiment was made on 6 groups of growing-finishing I-arge White pigs ( 36 castrated males and 36 females) between 25 and roo $\mathrm{kg}$ live weight. The pigs received pelleted diets based on maize and soybean oil-meal containing $17-18 \mathrm{p}$. Ioo crude protein. They were fed individually according to a restriction schedule depending on live weight and different according to sex.

During the growing period, between 25 and $60 \mathrm{~kg}$ live weight, replacement of half of the soybean protein by blood meal at a level of $6 \mathrm{p}$. Ioo (group 2) led to the same growth and feed intake performances (daily mean gain DMG : $692 \mathrm{~g}$; feed conversion ratio FCR : 2.40 ) as those obtained with the control diet (group I) containing maize and soybean oil-meal (daily mean gain : $657 \mathrm{~g}$; feed conversion ratio : 2.5 I). On the other hand, the introduction of a 2 p. roo blood meal as a total substitution of soybean protein (group 3) led to a reduction of the performances (DMG : $620 \mathrm{~g}$; FCR : 2.58). However, addition of 0.05 p. Ioo supplementary L-isoleucine (group 4) allowed resta- 
blishment of normal performances (DMG $660 \mathrm{~g}$; liCR : 2.53), but addition of tryptophan (group 0 ) appeared not to be necessary. Is a matter of fact, tryptophan supplementation alone (group 5) secmed to create an imbalance by excess leading to growth depression (6I5 g/day) and deterioration of the feed conversion ratio $(2.65)$.

During the finishing period, between 60 and oo $\mathrm{kg}$ live weight, the results obtained did not significantly differ from one treatment to another, but the two best treatments during the growing period (group 2 and 6 ) also appeared to be the best ones during the finishing period.

As regards the total growing-finishing period, substitution of half of the soyabean protein by blood meal (group 2 versus group I) improved by 6 p. Ioo the growth rate and by 4 p. Ioo the feed conversion ratio. Likewise, total replacement of soybean oil-meal by a supply of r 2 p. roo blood meal, supplemented with isoleucine $(0.05 \mathrm{p}$. Ioo) and tryptophan (0.03 p. Ioo), improved by 4 p. Ioo the growth rate and by 5 p. Ioo the feed conversion ratio. With respect to body composition, no difference between the treatments was noticed.

This experiment shows the advantage of using blood meal as protein replacer of soyabean oil-meal for fattening pigs. In terms of French pig production, blood meal (around 50 ooo tons), used as a replacer of $50 \mathrm{p}$. I oo of the supplementary supply of protein, might ensure the fattening of 3 millions of pigs per year

\title{
Energy value of dried beet-pulps and utilization by the growing-finishing pig
}

J. CHAUVEL, J. VILLAIN-GUILLOT* and D. BOURDON**

\author{
Institut technique du Porc, \\ 149, rue de Bercy, \\ 75579 Paris Cedex 12 \\ * Établissement Départemental de l'Élevage de l'Oise, \\ 3 , rue du Palais de Justice, \\ 60000 Beauvais \\ ** Station de Recherches sur l'Illevage des Porcs, I. N. R. A., C. N.R.Z., \\ 78350 Jouy en Josas
}

\section{Energy value}

The study included I 2 pigs (castrated Large White males) from 28 to $37 \mathrm{~kg}$, divided into 3 groups kept in metabolism crates. Group I received a control diet (maize-soyabean); groups 2 and 3 were fed with $20 \mathrm{p}$. Ioo dricd beet pulps in replacement of the maize soyabean mixture. No differences were recorded in the growth performances (but the period was short and the number of animals small) however 20 p. Ioo pulps increased the feed conversion ratio by 3 p. Ioo. Digestibility decreased linearly when the crude fibre content increased (i.e. pulp level). The digestible energy of beet pulp represented $2562 \mathrm{kcal} / \mathrm{kg}$ dry matter, the apparent digestibility coefficient of energy being 60.4 p. Ioo.

\section{Utilization of dried beet-pulps}

The three treatments described above were compared on 30 pigs (Io per treatment) from 26 to $98 \mathrm{~kg}$ liveweight. Growth performances were only slightly changed at the level of ro p. IOO pulps but the daily mean gain decreased by $5 \mathrm{p}$. Ioo and the feed conversion ratio increased by 